\title{
Imagining a new 'abnormal' amidst COVID-19: Seeking guidance from evolutionary anthropology and theology
}

\begin{tabular}{|c|c|}
\hline \multicolumn{2}{|c|}{$\begin{array}{l}\text { Author: } \\
\text { Bernice Serfontein }{ }^{1}\end{array}$} \\
\hline \multicolumn{2}{|c|}{ 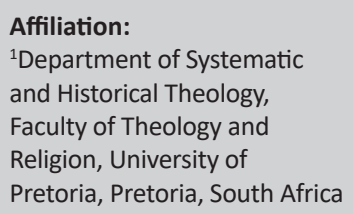 } \\
\hline \multicolumn{2}{|c|}{$\begin{array}{l}\text { Research Project Registration: } \\
\text { Project Leader: D.P. Veldsman } \\
\text { Project Number: } 01224719\end{array}$} \\
\hline \multicolumn{2}{|c|}{$\begin{array}{l}\text { Description: } \\
\text { Dr Serfontein is participati } \\
\text { in the research project, } \\
\text { 'Religious Experience from } \\
\text { an evolutionary perspecti } \\
\text { directed by Prof. Dr Danie } \\
\text { Veldsman, Department of } \\
\text { Systematic and Historical } \\
\text { Theology, Faculty of } \\
\text { Theology and Religion, } \\
\text { University of Pretoria. }\end{array}$} \\
\hline \multicolumn{2}{|c|}{$\begin{array}{l}\text { Corresponding Author: } \\
\text { Bernice Serfontein, } \\
\text { bernice.serfontein@gmail.com }\end{array}$} \\
\hline \multicolumn{2}{|c|}{$\begin{array}{l}\text { Received: } 01 \text { Feb. } 2021 \\
\text { Accepted: } 11 \text { Apr. } 2021 \\
\text { Published: } 28 \text { May } 2021\end{array}$} \\
\hline \multicolumn{2}{|c|}{$\begin{array}{l}\text { How to cite this article: } \\
\text { Serfontein, B., 2021, } \\
\text { 'Imagining a new "abnormal" } \\
\text { amidst COVID-19: Seeking } \\
\text { guidance from evolutionary } \\
\text { anthropology and theology', } \\
\text { HTS Teologiese Studies/ } \\
\text { Theological Studies 77(3), } \\
\text { a6519. https://doi.org/ } \\
\text { 10.4102/hts.v77i3.6519 }\end{array}$} \\
\hline \multicolumn{2}{|c|}{$\begin{array}{l}\text { Copyright:. } \\
\text { (C) 2021. The Authors. } \\
\text { Licensee: AOSIS. This work } \\
\text { is licensed under the } \\
\text { Creative Commons } \\
\text { Attribution License. }\end{array}$} \\
\hline Read online: & \\
\hline 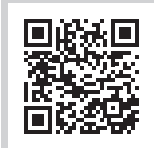 & $\begin{array}{l}\text { Scan this QR } \\
\text { code with your } \\
\text { smart phone or } \\
\text { mobile device } \\
\text { to read online. }\end{array}$ \\
\hline
\end{tabular}

The coronavirus disease 2019 (COVID-19) pandemic is responsible for the large-scale devastation experienced all over the world. This 'invisible stranger' interrupting our daily lives is highlighting in a new and acute way the vulnerability of the human race. Life as we knew it is being changed forever. COVID-19 also exposed the injustices embedded in social structures all over the world. What will life with and after COVID-19 look like in South Africa? The pandemic reveals that South Africa is not the fair and just society we hoped for since the transition to a democratic country in 1994. In light of this, we should be preparing ourselves for the new 'abnormal' as what seemed normal was problematic and therefore, truly abnormal. Seeking guidance from evolutionary anthropology, this article will explore whether the evolutionary story of Homo sapiens might offer us insights on how to successfully navigate the multiple challenges COVID-19 unmasks and also brings forth. A discussion on the evolutionary history of homo sapiens within the context of niche construction theory reveals that our unique capacity for imagination and creative collaboration made us successful as a species. It is these capacities for imagination and cooperation that might facilitate us in successfully imagining and thereafter living the new 'abnormal'. In this article, the question of imaging the new 'abnormal' will be explored.

Contribution: By creatively integrating the perspectives evident in this research, this article explores whether the Prophets of Israel might offer a feasible paradigm to determine coordinates for the imagined new 'abnormal' to be a more fair and just society.

Keywords: imagination; cooperation; niche construction theory; evolutionary anthropology; prophetic imagination.

\section{Introduction}

We are experiencing a unique disruptive moment of unprecedented proportions, in the history of the world. Both the present and the future are extremely unpredictable. Absolute certainties and statements are replaced by fragile sensations of new insight. The coronavirus disease 2019 (COVID-19) has revealed human creativity, the regularly neglected presence of nature as well as the resilience of communities. Equally, it has revealed profound social injustices, conceptual deficiencies and structural inadequacies regarding the way we shape our civilisation and knowledge (Hampton \& Thiessen 2020:15). In a recent online seminar themed, Theology in a time of COVID-19 (April 2020), ${ }^{1}$ it was mentioned that South Africa cannot prepare herself for the so-called new 'normal' during and after COVID-19, as what seemed to be normal in the past was problematic. ${ }^{2}$ The 'normal' was, in fact, a big 'abnormal'. As South Africa marks 26 years of freedom and democracy, COVID-19 exposes that we are not the equal, caring and just society we had anticipated. The various forms of injustice and inequality embedded in our socio-economic and political structures reveal that our society is far from the '1994-ideal' we had in mind. Taking this into consideration, we should be preparing ourselves for the new 'abnormal' during and after COVID-19.

Life with the uninvited invisible 'virus-stranger' has been challenging so far. Various individuals and organisations are assisting others by employing daily acts of compassion and kindness. One cannot help to wonder how far this compassion will extend. Theologian Celia Deane-Drummond (2020.) asks the question:

1.The seminar, broadcasted on 29 April, was an initiative of the Dutch Reformed Church with the following interlocutors: Nico Koopman, Robert Vosloo, Daniel Veldsman and Nadia Marais.

2.With the use of 'Normal' I refer to the usual, typical or expected state or condition. 
[C]an we, even in a time of great loss and mourning, still lift our faces to see and witness the continued suffering and death of other living creatures? Are we ready to engage the ecological virtues of love, gratitude, practical wisdom, discernment, justice, temperance and hope, through times of uncertainty and beyond in a post COVID-19 world? (p. ad loc)

COVID-19 can be regarded as a symptom of our lack of health as an earth community, but simultaneously it could be the trigger that sets in motion changes that will assist us in the long-term challenges of socio-economic inequality, various forms of injustices, climate change and ecological devastation.

How do we prepare ourselves for the new 'abnormal'? Life during and after COVID-19 is what I will be referring to as the new 'abnormal'. Seeking guidance from evolutionary anthropology, I want to ask if our evolutionary history might offer us insights on how to approach this disruptive moment in the life of Homo sapiens. ${ }^{3}$ This research explores how our unique capacity for creative imagination and collaboration might help us with the great task of realising the new 'abnormal'. To create this new way of life, we will need to revisit what humans do best, which is to be imaginative and creative about solving problems and work together. As Agustin Fuentes - American primatologist considered on the forefront of the discourse on human evolution - said in a recent interview on Kiro Radio on 20 April 2020 (Fuentes 2020a): 'Collaborate, cooperate, and exhibit compassion. That's what we've been doing for about 2 million years, and it's got us pretty far'. As a last note, I want to explore if the Prophets of Israel in the Old Testament might help us to give content to this imagination and creative collaboration. What guidance might they offer us in imagining an alternative society in South Africa?

\section{Niche construction theory and human evolution ${ }^{4}$}

Being a semiotic species is an essential element of our evolutionary success. The use of symbols and the evolution of imagination in our perceptions of, and dealing with, the world act as a key factor in human evolutionary histories. Against the background of niche construction theory, this research attempts to gain a broader understanding of human imagination and creative collaboration in H. sapiens. In a recent publication, Theology and Evolutionary Anthropology: Dialogues in Wisdom, Humility and Grace, Fuentes (2020b) draws attention to the following:

$[I] \mathrm{n}$ assessing the evolution of human beings we need not only explain the development of bodies and our modifications to ecologies, we also must develop a robust description for an evolving system that facilitates the production of Oldowan stone tools at 2 million years ago; more complex stone tool technologies

3. Homo sapiens sapiens, or modern man, is a sub species of Homo Sapiens and emerged about $40000-130000$ years ago. Van Huyssteen (2017b:171) in agreement becoming Human (H. Sapiens) to being Human (H. Sapiens Sapiens). The term Homo Sapiens Sapiens is often foreign to readers and therefore I will mainly use Homo Sapiens Sapiens is often foreign to readers and ther
Homo Sapiens when referring to modern human beings.

4.An extensive discussion on niche construction theory and Human evolution can be found in a previous publication of mine, Imagination, religion and morality: An interdisciplinary approach (Serfontein 2019). and widening geographic spread starting $~ 1.8$ million years ago; substantive increases in overall cooperation and specifically the coordination of caretaking activities, the use and control of fire, and complex hunting and materiality by 400,000 years ago; art and increasingly complex multi-community social networks by $\sim 120,000$ years ago; domestication by $15,000-10,000$ years ago; early cities by 5,000 years ago and the megacities, global religions, and world economies of today. (p. 15)

As pointed out by Fuentes (2009:12), an extensive body of research and theory is inadequately captured under the two headings: 'Darwinian' and 'neo-Darwinian'. Basic neo-Darwinian theory argues that natural selection and sexual selection are the main forces of evolutionary change as well as the emergence of adaptations. Yet, there are many more to evolution than merely the inheritance of genes. Therefore, it is necessary to offer a broad perspective on evolution, which demands an intentional shift away from approaches that are limited to either social or biological focusses (Serfontein 2019:2). Such a perspective also dismisses any explicit prioritisation in inheritance systems (Van Huyssteen 2017a:4). Niche construction theory accordingly views evolution as 'construction' and argues that evolution is never just a matter of a biologically developing organism. Rather, as Van Huyssteen (2017a:4) asserted, evolution is a matter of organism-environment systems changing gradually with time in a dynamic and interactive niche construction process.

Particular evolutionary histories and processes in the human niche gave rise to distinctive development and expansion of human cognitive processes and neurobiology. This makes it possible for humans to develop substantial detached mental representations, hyper-creativity, linguistic and symbolic communication and particularly powerful capacity for imagining (Fuentes 2020b:14). Consequently, human beings are susceptible to influence, with potentially evolutionarily relevant implications, from both specifically cued material and transcendent experiences. Fuentes (2020b:14) mentioned that this cognitive, experiential, perceptual and social complexity and diversity in our social and ecological milieus enable humans to experience, create and develop skills in perception and awareness that are highly diverse and not contingent on material reality. Transcendental experiences, such as religious beliefs, practices and sensations may be included as a central process in the construction and navigation of the human niche (Fuentes 2019:47; Montagu 1965:2-3). Therefore, the human niche - and potentially evolutionarily relevant human experience - is not necessarily bounded by material borders.

Integration across diverse modes of inquiry, especially those that engage with some transcendental components as a core premise, might be particularly helpful when asking questions about human beings. This stresses the importance of employing an epistemological framework that encompasses the critical interlocking systems of the human niche in any discussion on human evolution. Following this perspective, the making, navigating and sharing of meaning are as central to human evolution as are bones, local ecologies 
and stones. Anthropologist Maurice Bloch notes the importance of a transdisciplinary approach to the question of what it means to be human (Bloch 2008:258). The human experience as a whole - past, present and future - is characterised by being simultaneously transactional and transcendent (Bloch 2008:258). Therefore, scholarly discussion on this subject can benefit from discourse that integrates, engages and interweaves diverse theoretical, philosophical and theological perspectives. As Fuentes (2020b:17) articulated it: 'The perceptual and experiential play a core role in human becomings, evolutionary and otherwise'. Consequently, transdisciplinary study is of the utmost importance in seeking any responsible conclusions on what it means to be human.

Comprehending the distinctive evolutionary history of humans is not merely understanding that we have so much in common with our evolutionary counterparts, but rather to understand what happened during the last 2 million years in our genus. ${ }^{5}$ Numerous scholars (Antón, Potts \& Aiello 2014; Foley 2016; Fuentes 2020b; Gamble, Gowlett \& Dunbar 2011) agreed that over the past 2 million years, the human lineage underwent notable morphological changes together with significant, but difficult to measure, behavioural and cognitive modifications as it forged and was shaped by, new niches - human niches. In short, evident across the Pleistocene ${ }^{6}$ is the emergence of a human niche. This niche is simultaneously ecological, material, perceptual and eventually, metaphysical. Currently, the human niche is the ecological, spatial and social sphere that contains all ecologies, perceptual contexts and social partners of human individuals, groups and communities as well as the many other species that exist with and alongside humans (Fuentes 2020b:17). A key facet of the human niche is effectively described by Deacon (2016:136) as the 'ubiquitous semiotic ecosystem in which we develop: an encompassing and dynamic context for human lives which is simultaneously ecological, material, imagined, perceived, and constructed'. Within the context of this niche, humans interact with, interface, alter and are altered by, ecological and social pressures during their development. Human niches also consist of ideologies, institutions and practices. Fuentes (2020b:18) noted that human niches are the context for the lived experience of humans and their communities. In a nutshell, during the Pleistocene, the human lineage developed a distinctive set of neurological, physiological and social skills that enabled us to think together and work together to create and collaborate at cumulative levels of complexity. This collaboration intrinsically involves a capacity for imagination, the intensification of the use of signs and the creation and use of symbol (Fuentes 2020b:21). Ultimately, the human niche is thoroughly social and cooperative, connected to increased capacities to share information and collaborate and relies profoundly on the use and altering of materials outside our bodies to create new solutions to the challenges of the world.

5. Humans are animals, mammals, primates, and hominoids. But we are also hominins, specifically genus Homo, species sapiens (Fuentes 2020b:14).

6.The Pleistocene is considered as the geological era that lasted from about 2580000 to 11700 years ago.

\section{Imagination and cooperation in the human niche}

The insights of several authors (Foley 2016; Fuentes 2019, 2020b; Spikins, Rutherford \& Needham 2010; Sterelny 2012; Tomasello 2019) enable us to argue that the human capacity for creative cooperation - especially the ability to think, communicate and collaborate with increasing skill-facilitated the development of a lineage capable of developing our contemporary human niche. This collaborative and imaginative capacity for creativity is also the suite of processes and capabilities that laid the path for the development of ethical and judicial systems, and religious dogmas and the production of masterful works of art. Unfortunately, it is these capacities that also tragically stimulated and facilitated our ability to compete in more lethal ways - to colonise and oppress other members of our species, to wage war, to systematically dehumanise and to manipulate and abuse the planet to the verge of ecological devastation.

\section{Human imagination}

As is evident in archaeological and fossil records, our hominin ancestors and relatives did undeniably have imaginative capacities that were functional in their day-to-day living (Mithen 2007:3). Our hominin ancestors usually applied these imaginative capacities whilst hunting and gathering or the making of stone tools was considered. There is, however, no evidence of creative imagination in these records. The creative imagination was most likely restricted to $H$. sapiens. Mithen (2007:3) identified seven key developments over a long period of biological and cultural evolution which gave rise to the creative imagination distinctive of $H$. sapiens: (1) the development of the theory of mind, (2) a uniquely human life history, (3) domain-specific intelligences, (4) the emergence of music and language, (5) cognitive fluidity, (6) the extended mind and (7) the appearance of sedentary farming lifestyles. ${ }^{7}$ Within the perspective of niche construction theory, the human capacity for imagination developed as a response to the numerous ecological and social challenges genus Homo confronted during the Pleistocene. According to Fuentes (cf. 2014, 2017), this capacity for imagination in turn enabled the origin of other capacities known to humans, such as art and religion. The combination of fossil and archaeological evidence with a niche construction perspective, as well as highlighting the role of complexity in human evolution, increases our understanding of a uniquely human way of being in this world (Fuentes 2014:247). Fuentes (2014, 2017) further pointed to the notion that the earliest material evidence of imagination is detected in the latter part of the Pleistocene, and therefore, a study of this particular time period is crucial in exploring the origin of imagination. The earliest evidence of imagination includes simple edged stones and sharp flakes as the most primitive tool manufacturing. The fabrication of these simple tools indicates the human lineage's ability to envision more than what is simply in front of them and to generate new form and function in the world.

7.For a detailed discussion see Serfontein (2018). 
Because of the human capacity for imagination, our world is extremely complex. Human beings developed a unique niche during the course of our evolution. Characteristic of this niche is the use of symbols and imagination which are main features in our ecology, and in essence, it is a part of what we might call the 'human toolkit'. By the late Pleistocene, genus Homo confronted myriad ecological and social challenges. Bearing those challenges and the complexity of their niche in mind, Fuentes (2014) stated that:

$[O]$ ne can viably argue that being able to deploy cognitive and behavioural processes that incorporate a sense of imagination and hope, while risky, could increase the likelihood of innovation and successful responses to evolutionary challenges. (p. 251)

In accord with Fuentes (2014:251), this view - along with current research on the role of compassion, meaning-making and social networks, as well as the connection between stone tool manufacturing and ritual, the emergence of 'art' and symbols in the archaeological record and the continuing assertion that human beings are undeniably a symbolic species - offers an evidentiary context in which the origin of this temporary complex, semiotic and imaginative reality for genus Homo is detectable.

\section{Human cooperation}

In a fascinating recent publication, Becoming Human: A Theory of ontogeny (2019), Michael Tomasello explores how humans have evolved a set of species-unique cognitive and social skills for coordinating with others in various innovative forms of cooperative interaction. The evolution of these uniquely human adaptations for cooperation took place in two main steps (Tomasello 2016, 2019:10; Tomasello et al. 2012). Firstly, humans developed into obligate collaborative foragers to the extent that individuals were inter-reliant with one another and therefore had a direct awareness of the wellbeing of their partners. In this setting, humans developed the skills and motivations of joint intentionality. Secondly, as humans faced competition from other groups, these novel collaborative skills and motivations were expanded and consequently enabled modern human individuals to cooperate in the larger collaborative enterprise known as culture. These are the skills and motivations of collective intentionality. Tomasello et al. (2012:681) mentioned that as human individuals becameincreasingly moreinterdependent, human cognition and sociality became increasingly more collaborative and altruistic, which ultimately resulted in large-group cooperation along with its complex conventions, norms and institutions.

It can be said that shared intentionality brought about a monumental transformation of human ontogeny (Tomasello 2019:342). In a broader evolutionary scheme, it represents the capacity of human beings to come together interdependently to act as single agents - either jointly between individuals or collectively amongst the members of a group. The fact that individuals adopt a shared goal, adjust the performance of their role to coordinate with partners, share the spoils of their efforts and so forth, all of these point to the notion that they are indeed acting together as a single agent. Perhaps most significantly, as Tomasello (2019:342) argued, human beings in a shared agency collaborate as a 'we' to self-regulate their collaborative activity. At the level of both joint and collective intentionality, the basic structure is, as Tomasello (2019:342) explained: 'we > me mode of operation in which "we" selfregulate each of us as individuals'. This voluntary submission of 'me' to 'we' is an indication that the participants recognise themselves to be functioning interdependently as a single agent, whose powers of accomplishment and normative force transcend those where either a participant possesses on his or her own as an individual.

On this notion of collective intentionality and large-group cooperation, Fuentes (2017:83) argued that the creation of communities should be viewed as a dynamic force in our evolutionary trajectory, and not simply an outcome. No other species work together to collect, prepare and share food in the way humans do. Fuentes (2017:85) asserted that human beings deal with all the problems the world tosses at them as a community. It can be said that humans have a distinctive capacity for getting and acting together, or as Fuentes (2017:86) puts it, "it is part of our niche, the way we "make it" in the world'. Also, nothing else on this planet expresses the kind of massive compassion and coordination in the face of adversity as humans repeatedly do (Fuentes 2017:86). The development of cognitive flexibility in response to ecological and social challenges is a significant feature behind the development of H. sapiens. Henriksen (2020:148) argued that wisdom is an expression of this flexibility, which could be viewed as a consequence of the theory of mind and the symbolically mediated capacity for cooperation and the sharing of alternative visions of the future. To have common visions not only embedded in the past but also projecting possible futures might also change our actual experience of the world (Henriksen 2020:148). I believe it is these increased capacities for imagining solutions to new challenges and realising them through cooperative collaboration, which might facilitate our society in successfully navigating the multiple challenges COVID-19 places in front of us.

\section{A new 'abnormal'?}

The question inevitable arises: What content should be given to our imagination of the new 'abnormal'? The Prophets of Israel might have something to say to us in this regard. What they might have to say, I find convincingly insightful in the expositions of Brueggemann (2018 [1978]) and Stulman and Kim (2010) on prophetic literature. In his work, The Prophetic Imagination, first published in 1978, Walter Brueggemann translates the imagination of the Prophets from the chaos of the ancient world to our world today. Stulman and Kim (2010) explained that prophetic literature is both disaster and survival literature. These texts serve as a 'meaning-making map of hope' for victims of devastating circumstances (Stulman \& Kim 2010:7). In this capacity, prophetic literature challenges the politics of injustice and refuses to let death and destruction have the final say. Most astoundingly, as Stulman and Kim (2010:7) 
put it, prophetic literature deploys the language of hope to imagine a future when none seems possible.

There is a dominant conservative misconception with regard to the role of a prophet in the Old Testament, namely that the prophet is a predictor of things to come in the future. Such a view, however, leans towards a mechanical reductionism because the prophets are concerned with the future as it imposes upon the present. According to Brueggemann (2018 [1978]:3), 'the task of the prophetic ministry is to nurture, nourish, and evoke a consciousness and perception alternative to the consciousness and perception of the dominant culture around $\mathrm{us}^{\prime} .{ }^{8}$ The purpose of the alternative consciousness to be cultivated is two-fold: firstly, to criticise the dominant consciousness in the process of dismantling it, and secondly, this alternative consciousness should energise individuals and communities by its promise of another time and situation towards which they may move (Brueggemann 2018 [1978]:3). This process is what Brueggemann labelled the Prophetic Imagination (1978). In short, three basic steps form part of the prophetic imagination: firstly, with honest cries over pain and loss that result from social injustices, it refuses denial and penetrates despair; secondly, it evokes memory by drawing on ancient, artistic traditions that energise the community to imagine and live into a more just order and thirdly, it ends in hope and gratitude for the surprising gift of an emancipated future (Hankins 2018:xiv). Thus, the prophets imagined an alternative future by using fragments of the past and present as coordinates in this process. Brueggemann (2018 [1978]:9) explained how the narrative of the Exodus is designed to show the radical criticism and radical discrediting of the Egyptian empire. Moses deconstructs the politics of oppression and exploitation by opposing it with a politics of justice and compassion. The reality emerging out of the Exodus is not simply a new religion or vision of freedom, but the emergence of a new social community, representative of the alternative consciousness characterised by justice and compassion. The participants in the Exodus found themselves, according to Brueggemann (2018 [1978]:8), involved in the intentional formation of a new social community resembling the vision of God's freedom. The radical movement of Moses is continued by the Prophets of Israel, such as Jeremiah and Second Isaiah (Brueggemann 2018 [1978]:115). Ultimately, in most radical form, Jesus of Nazareth practised the main elements of prophetic imagination. In a certain way, Jesus becomes the embodiment of an alternative consciousness. In his solidarity with the marginalised, Jesus is moved to compassion. Compassion which, according to Brueggemann (2018 [1978]:88), constitutes a radical form of criticism, as it proclaims that suffering is to be taken seriously, that suffering is not to be accepted as normal and natural but is an abnormal and unacceptable condition for all of God's creation. Brueggemann (2018 [1978]:3) suggested that prophetic imagination has to do not primarily with addressing a specific public crisis, rather it should address the dominant crisis that is enduring and resilient over time. From an economic perspective in South Africa, as an example, this means that prophetic imagination needs to address not the overpaid CEO, government official or the misappropriation of municipal funds, but rather the dominant social and economic ideologies that facilitate steadily increasing divergences in wealth distribution. The next important question to be asked is not only whether our economic system has enabled growth and benefited the lives of all, but whether we can imagine an alternative kind of economy, characterised by justice, that might promote broader benefits for all of creation in the future. The same paradigm can be applied to the various other ideologies which sustain our current social structures.

The current system failure, as revealed by COVID-19, is thousands of years in the making and touches on every aspect of society. There are, however, no quick fixes to this dilemma, and it is, therefore, necessary for us to reinvent our culture and our institutions from the bottom up. As David Korten (2020) appropriately noted:

[T]his COVID-19 is humanity's wake-up call. As we awaken to the truth of the profound failure of our existing institutions, we also awaken to the truth of our possibilities and interconnections with one another and with Earth. With that awakening comes a recognition that we must now learn to live lightly on the Earth, to war no more and to dedicate ourselves to the well-being of all in an interdependent world. (p. ad loc.)

Fortunately, as Hampton and Thiessen (2020:17) remind us, this pandemic prompts us to collectively reflect upon our inherited social imaginary with fresh perspectives. Consequently, we begin to envision alternative possibilities for the flourishing of both human and non-human life. Following this viewpoint, the new 'abnormal' for South Africa invites us to imagine an alternative system, with selfless leaders committed to effective government for the well-being of all of creation which depends largely on healthy institutions in the government, business and civil society sectors. We are prompted to imagine a new 'abnormal' in which the dignity of all living creatures is affirmed and respected. This means a society in which each living creature should at least have access to enough resources to provide for their most basic needs. A new 'abnormal' for South Africa is characterised by justice and fairness. COVID-19 inevitably leaves us with a decision to make ... Will the current pandemic crisis be seised as an opportunity to address the profound structural, social and ecological challenges that we brought with us into this second decade of the new millennium, or will we collectively, even if hesitantly and unwillingly, continue with the same destructive perceptions and practices that we previously held?

\section{Conclusion}

In answering the question of what this new 'abnormal' should look like in South Africa, implementing the paradigm of prophetic imagination via critically evaluating the past and current consciousness and consequently imagining a 
new alternative consciousness might bring us closer. Critical evaluation of the current consciousness reveals that this global health pandemic has highlighted the injustices embedded in social structures all over the world. The challenges we are currently facing and will continue to face into the future made us aware, more than ever before, of the necessity for an integrated approach that attempts to give a preferential option for the marginalised in society and to defend life in all its diversity and richness.

Just as the COVID-19 crisis brings forth peril, it also opens up opportunity. Following the Prophets of Israel and Jesus of Nazareth, we should mourn as well as criticise those actions that enable the persistence of situations that compromise core values of justice and compassion and imagine alternative conventions that define the interests of all based on those values. We as a society should be critical about our current failings to imagine a better, alternative consciousness. Our distinctive human capacity for shared intentionality and creative cooperation coupled with our imagination is how we became who we are today. As Fuentes (2017:292) reminds us, being human is a creative process and our ancestors set the stage for us by living creative and cooperative lives as both individuals and in groups. It would be a shame if we let that go in waste. Understanding the details of how the human creative process worked concerning the way our ancestors dealt with the planet and one another, and channelled creative energies and capacities into ever-expanding innovations can give us a better grasp of our place in the world and help us shape our future. Our evolutionary story tells us how we came from a small group in the hominin lineage that expressed extreme forms of compassion, could make simple stone tools and creatively cooperate to survive the challenges faced, to the creators of art, science, religion, cities, nations and more. Once we recognise and value our ability to imagine solutions and realise them through collaborative effort, the greatest challenge we face is managing the inevitable failures. The challenges we continue to face have grown in scale, as is evident in a time of COVID-19. But that is just all the more reason for our next steps to be all the more creative.

\section{Acknowledgements}

B.S. is the sole author of this research article.

\section{Competing interests}

The author declares that she has no financial or personal relationships that may have inappropriately influenced her in writing this article.

\section{Author's contributions}

The author declares that she is the sole author of this research article.

\section{Ethical considerations}

This article followed all ethical standards for research without direct contact with human or animal subjects.

\section{Funding information}

This research received no specific grant from any funding agency in the public, commercial or not-for-profit sectors.

\section{Data availability}

Data sharing is not applicable to this article as no new data were created or analysed in this study.

\section{Disclaimer}

The views and opinions expressed in this article are those of the author and do not necessarily reflect the official policy or position of any affiliated agency of the author.

\section{References}

Antón, S., Potts, R. \& Aiello, L., 2014, 'Evolution of early homo: An integrated biological perspective', Science 345(6192), 1236828. https://doi.org/10.1126/science.1236828

Berger, P., 1967, The sacred Canopy: Elements of a sociological theory of religion, Doubleday, Garden City, NY.

Berger, P. \& Luckmann, T., 1966, The social construction of reality: A treatise in the sociology of knowledge, Doubleday, Garden City, NY.

Bloch, M., 2008, 'Why religion is nothing special but is central', Philosophical Transactions of the Royal Society B 363(1499), 2055-2061. https://doi. org/10.1098/rstb.2008.0007

Brueggemann, W., 2018 [1978], Prophetic imagination Brueggemann: 40th anniversary edition, Fortress Press, Minneapolis, MN.

Deacon, T., 2016, 'On human (symbolic) nature: How the word became flesh', in G. Etzelmüller \& C. Tewes (eds.), Embodiment in evolution and culture, pp. 129-149, Mohr Siebeck, Tübingen.

Deane-Drummond, C., 2020, Four lessons from Laudato Si' amidst Covid-19 pandemic viewed 20 May 2020, from https://www.jesuit.org.uk/four-lessons-laudato-siamidst-covid-19-pandemic.

Foley, R.A., 2016, 'Mosaic evolution and the pattern of transitions in the Hominin Lineage', Philosophical Transactions of the Royal Society B: Biological Sciences 371(1698), 20150244. https://doi.org/10.1098/rstb.2015.0244

Fuentes, A., 2009, Evolution of human behaviour, Oxford University Press, Oxford.

Fuentes, A., 2014, 'Human evolution, niche complexity, and the emergence of a distinctly human imagination', Time and Mind 7(3), 241-257. https://doi.org/10.1 080/1751696X.2014.945720

Fuentes, A., 2017, The creative spark: How imagination made humans exceptional Penguin Random House LCC, New York, NY.

Fuentes, A., 2019, Why we believe: Evolution and the human way of being, Yale University Press/Templeton Press, New Haven, CT.

Fuentes, A., 2020a, 'Double down on efforts toward community to get through COVID-19', Interviewed by Nights, K., Kiro Radio 97.3 FM. 20 April, 06:00 AM viewed 29 May 2020, from https://mynorthwest.com/1822166/efforts-towardcommunity-covid19/?

Fuentes, A., 2020b, 'Setting the stage developing the human niche across the Pleistocene', in C. Deanne Drummond \& A. Fuentes (eds.), Theology and evolutionary anthropology: dialogues in wisdom, humility and grace, pp. 13-28, Routledge, New York, NY.

Gamble, C., Gowlett, J. \& Dunbar, R., 2011, 'The social brain and the shape of the palaeolithic', Cambridge Archaeological Journal 21(1), 115-136. https://doi. org/10.1017/S0959774311000072

Hampton, A.J.B. \& Thiessen, A.R., 2020, Pandemic, ecology and theology (Routledge, Abingdon Focus on Religion), Kindle edn., Routledge, Abingdon.

Hankins, D., 2018, 'Foreword', in W. Brueggemann (ed.), Prophetic imagination: 40th anniversary edition, Fortress Press, Minneapolis, MN

Henriksen, J.O., 2020, 'An animal in need of wisdom theological anthropology and the origins of humility and wisdom', in C. Deanne-Drummond \& A. Fuentes (eds.) Theology and evolutionary anthropology: Dialogues in wisdom, humility and grace, pp. 142-159, Routledge, New York, NY.

Korten, D. 2020, 'Why coronavirus is humanity's wake-up call', Yes! Solutions Journalism, 18 March, viewed 02 November 2020, from https://www. yesmagazine.org/opinion/2020/03/18/coronavirus-wake-up-call/.

Luckmann, T., 1967, The invisible religion: The problem of religion in modern society, MacMillan, New York, NY.

Mithen, S.J., 2007, 'Seven steps in the evolution of the human imagination', in I. Roth (ed.), Imaginative minds, pp. 3-30, Oxford University Press, Oxford.

Montagu, A., 1965, The human revolution, Bantam, New York, NY.

Serfontein, B., 2018, 'Imagination, religion, and morality: An interdisciplinary approach', PhD thesis, University of Pretoria. 
Serfontein, B., 2019, 'Imagination, religion and morality: An interdisciplinary approach', HTS Teologiese Studies/Theological Studies 75(1), a5350. https://doi. org/10.4102/hts.v75i1.5350

Spikins, P., Rutherford, H. \& Needham, A., 2010, 'From homininity to humanity: Compassion from the earliest archaics to modern humans', Time and Mind 3(2) 303-326. https://doi.org/10.2752/175169610X12754030955977

Sterelny, K., 2012, The evolved apprentice: How evolution made humans unique, MIT Press, Cambridge, MA.

Stulman, L. \& Kim, H.C.P., 2010, You are my people: An introduction to prophetic literature, Abingdon Press, Nashville, TN.

Tomasello, M., 2016, A natural history of human morality, Harvard University Press, Cambridge, MA.
Tomasello, M., 2019, Becoming human: A theory of ontogeny, Harvard University Press, Cambridge MA.

Tomasello, M., Melis, A., Tennie, C., Wyman, E. \& Herrmann, E., 2012. 'Two key steps in the evolution of human cooperation: The interdependence hypothesis', Current Anthropology 53(6), 673-92. https://doi.org/10.1086/668207

Van Huyssteen, J.W., 2017a, 'Lecture one: Rediscovering Darwin for theology Rethinking human personhood', HTS Teologiese Studies/Theological Studies 73(3) a4485. https://doi.org/10.4102/hts.v73i3.4485

Van Huyssteen, J.W., 2017b, 'Human origins and the emergence of a distinctively Human imagination: Theology and the Archaeology of Personhood', in A. Fuentes \& A. Visala (eds.) Verbs, bones, and brains: Interdisciplinary perspectives on human nature, pp. 165-189, University of Notre Dame Press, Notre Dame, IN. 